\title{
System dynamics model for sustainable water supply strategy in Sentul City area
}

\author{
Danang Aria Pranedya Baskoro ${ }^{\mathrm{a}}$, Atep Hermawan ${ }^{\mathrm{b}}$, Tri Permadi ${ }^{\mathrm{b}}$ \\ ${ }^{a}$ Agricultural Engineering Chapter, The Institution of Engineering Indonesia, Darmaga, Bogor, 16680, Indonesia [+62 81285308990] \\ ${ }^{\mathrm{b}}$ Evironmental Research Center, IPB University, Darmaga, Bogor, 16680, Indonesia [+62 251-8621085]
}

\section{Article Info:}

Received: 21 - 04 - 2021

Accepted: 09 - 06 - 2021

Keywords:

System dynamic, water management, water sensitive city

Corresponding Author: Danang Aria Pranedya Baskoro Badan Kejuruan Teknik Pertanian, Persatuan Insinyur Indonesia;

Tel. +6281294592090

Email:

ariapranedya@gmail.com

\begin{abstract}
Good management of water resources is a requirement for an area with a high population development. Sentul City, which is an independent city in Bogor Regency which has a high population, is in an area that lacks water. Because of this, Sentul City requires infrastructure and policies that can ensure the availability of water for its residents. One of the paradigms of water management in urban areas is a water-sensitive city. One of the steps in this paradigm is wastewater management and rainwater harvesting. The system dynamics modeling method is used to predict the impact of implementing several policies that will be taken to manage water resources. This study aims to build dynamic models to predict water supply and demand and analyze policies for wastewater management and rainwater harvesting. Sentul City water demand is estimated will reach $122105000 \mathrm{~m}^{3}$, and a water crisis will occur in 2027. The wastewater recycle policy can inhibit water crisis until 2030, and the negative water balance will last until 2040. Combining wastewater recycle and rainwater harvesting can increase water availability by $240 \%$ and prevent a water crisis.
\end{abstract}

How to cite (CSE Style $8^{\text {th }}$ Edition):

Baskoro DAP, Hermawan A, Permadi T. 2021. System dynamic model for sustainable water supply strategy in Sentul City area. JPSL 11(2): 233-240. http://dx.doi.org/10.29244/jpsl.11.2.233-240.

\section{INTRODUCTION}

Indonesia in 2000, on the island scale level of water available, showed a degree of scarcity, especially in Java Island. Until 2045, the level of water availability in Java, Bali, West Nusa Tenggara, and Southern Sulawesi was critical (BAPENAS, 2019). High city population growth requires access to facilities and infrastructure to increase land conversion and water needs. Brown (2008) states water is essential for human activities in the city. This condition forces that a city must be able to maintain the quality and quantity of water because water is the center health of the city. Sentul City is an independent city in Bogor Regency designed with the principle of green development with the concept of eco-city. Sentul City is an area developed in waterscarce regions because the texture of the soil is dominated by clay texture.

There are three sources of water supply to fulfill the current needs of Sentul City. PDAM (Local Water Supply Utility) Tirta Kahuripan currently provided 200 1/s, Sentul City water treatment plant 80 1/s, and Sentul City wastewater treatment plant 0.03 1/s. Based on existing sources capacity, Sentul City can fulfill water needs of about $280.03 \mathrm{l} / \mathrm{s}$ or $16130 \mathrm{~m}^{3} /$ day (Hermawan et al., 2020). Harahap (2018) predicted that in 2050 Sentul City could only fulfill $59.90 \%$ of water needs because of population growth that increases water demand. Sentul City targeted 200000 people in 2050 and needs $15492060 \mathrm{~m}^{3} /$ year of water supply, assumed that water supply $5887351 \mathrm{~m}^{3} /$ year (existing water supply), there will be a water scarcity in Sentul City. 
The government of Bogor Regency and Sentul City Management plans for implementing rainwater harvesting that part of the Water Sensitive City (WSC) paradigm for water management sustainability. Water sensitive city is a city that utilizes capabilities holistically in the management of water resources in the city, not flooded in the rainy season and not drought in the dry season. The first two steps of WSC are provided water supply and wastewater water management/water recycle (Brown et al., 2009). The change from each stage is based on city population growth and government policy (Jun et al., 2012). Management of water resources model built to predict the performance of policies implemented by the government.

The system dynamics model in this study serves to simulate the implementation of the policies that have been formulated. This method can help understand the system by exploring the important structure of the mechanism and analyzing the feedback in the system that can be used as a reference for the management of water resources strategies efficiency (Park et al., 2015). Furthermore, the simulation can predict raw water availability and water demand in the Sentul City Region in the next few years and variables that can significantly affect the water balance; thus, system dynamics modeling for water supply management can reference making appropriate water resources management policies. The objective of this study is for built system dynamics to predict the water supply and demand in Sentul City urban area and then to predict the impact of water policies in Sentul City urban area.

\section{METHOD AND MATERIAL}

\section{Study Area}

The study area is in Sentul City, Bogor Regency, West Java Province, Indonesia, an upstream of Bekasi Watershed. Geographically at $06^{\circ} 33^{\prime} 55^{\prime \prime}-06^{\circ} 37^{\prime} 45^{\prime \prime} \mathrm{S}$ and $106^{\circ} 50^{\prime} 20^{\prime \prime}-106^{\circ} 57^{\prime} 10^{\prime \prime} \mathrm{E}$ (Figure 1). Sentul City is an integrated area that combines residential, commercial, tourism, and public facilities. The area of Sentul City is 2905.83 ha and is located in two sub-District, Babakan Madang and Sukaraja.

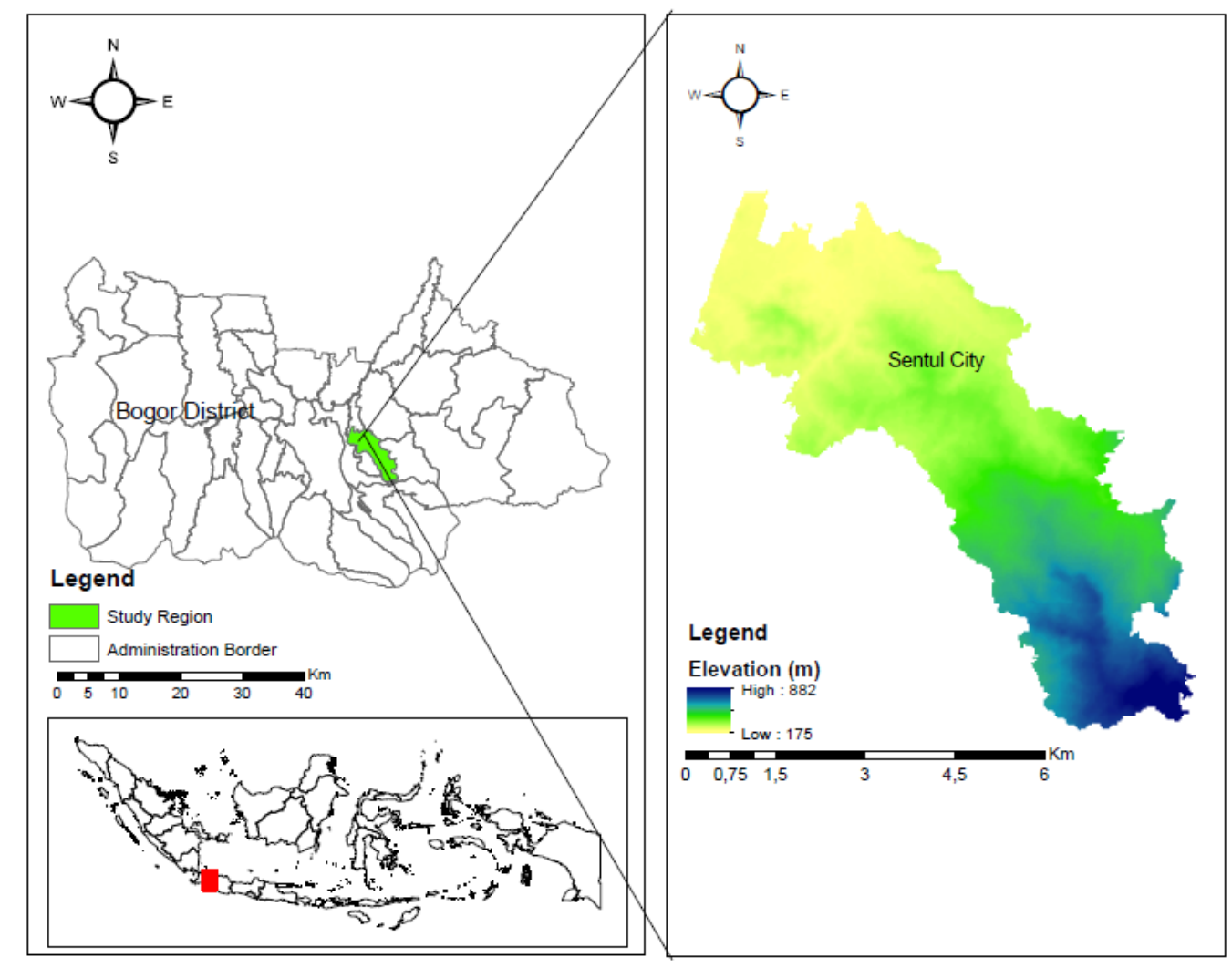

Figure 1 Study area (Sentul City, Bogor District) 


\section{Data and Tools}

The tools used in this study are ArcGIS 10.4 for spatial analysis and Vensim PLE for building system dynamics. Spatial analysis in this study is for a total determined area of Sentul City and calculate rainfall potential in Sentul City Area. The data for this study rainfall in 2010-2019 period, Sentul City master plan, Sentul City population, and existing water supply.

\section{Population Growth}

According to Meyer and Ausubel (1999), population growth is calculated by logistically increasing carrying capacity which is described in equation (1). Logistically increasing carrying capacity method can limit growth with a non-fixed capacity, which means population growth depends on carrying capacity/resources. $\mathrm{P}_{\mathrm{n}}$ is population in year $\mathrm{n}, \mathrm{P}_{0}$ is the initial population at the beginning of model simulation, $\alpha$ is population growth rate, $\mathrm{K}$ is the initial capacity (estimation maximal population of sentul city, 200000 people), $K_{n}$ is reached capasity in year $n$.

$$
\begin{gathered}
P_{n}=P_{0}+\alpha P_{0}\left(1-\left(\frac{K_{n}}{K}\right)\right) \\
D W C_{n}=365 P_{n} S D
\end{gathered}
$$

Baskoro et al. (2020) states that domestic water consumption is multiplication and individual standard water consumption (equation 2). Thus, $\mathrm{DWC}_{\mathrm{n}}$ is domestic water consumption in year $\mathrm{n}, \mathrm{P}_{\mathrm{n}}$ is a population in year $\mathrm{n}$, and $\mathrm{SD}$ is standard individual water consumption $\left(0.12 \mathrm{~m}^{3} /\right.$ day $)$.

\section{Water Consumption}

Sentul City water consumption is accumulated by domestic, commercial area, and public facility water consumption necessary for an independent city area (equation 3). Domestic water consumption is water that used for daily activities of Sentul City resident, commercial water consumption is water that used in the economic sector (hotel, department store, office, and traditional market), and public facility water consumption is water that used in basic human need sector (school, hospital, and worship place).

$$
\text { Water Consumption }=\mathrm{DWC}+\mathrm{CWC}+\mathrm{PWC}
$$

Where DWC is domestic water consumption $\left(\mathrm{m}^{3}\right), \mathrm{CWC}$ is commercial water consumption $\left(\mathrm{m}^{3}\right)$, and PWC is public water consumption $\left(\mathrm{m}^{3}\right)$.

\section{Rainwater Harvesting}

The potential rainfall in Sentul City was determined using average annual rainfall. Potential rainwater harvesting is calculated by urban water balance that changes along with urban spatial policy of the administrative region $(\mathrm{Li}, 2010)$. Rainwater harvesting (equation 4$)$, based on precipitation $(\mathrm{P})\left(\mathrm{m}^{3}\right)$, administrative area $\left(\mathrm{m}^{2}\right)$, and runoff coefficient $(\mathrm{Q})$. Runoff coefficient value in rainwater harvesting can be assumed by 0 because there is a government effort to keep rainwater maximally (Baskoro et al., 2020).

$$
W h=P A(1-Q)
$$




\section{System Dynamic Model}

The system dynamics model in the analysis process uses Vensim PLE software. Building an understanding of system dynamics model in general, according to Koushali et al. (2015), has several stages, namely defining problem in the field, determining significant variables to the system, determining mathematical equation that can describe the behavior of the system, and determining the time period of the simulation. Determining variables that describe the behavior of a system can be done using several criteria:

1. These variables are important and significantly influence system behavior. This depends on the restrictions made by modelers, factors outside the system are considered not important and are not taken into account in making the model.

2. Similar variables must be combined because a few factors will avoid unnecessary complexity.

3. Variables must be precisely defined.

The system dynamics method needs to generalize the pattern of behavior of the system in casuistic after modelers can determine the variable. The system's behavior must be understood in causal relationship/feedback loops that will form a system structure. The system dynamics model that is made consists of a basic model (business as usual/BAU) and a model with a scenario. The basic model of a system dynamics is a system that occurs today without any policy intervention being implemented. The system dynamics simulation uses three scenarios:

1. The BAU scenario is the current system.

2. The scenario of using recycled water from Sentul City's consumption waste is assumed to increase every year based on total water consumption, and the efficiency of the wastewater treatment is $65 \%$.

3. Rainwater harvesting scenarios that are assisted by the use of recycled water as in scenario 2. Assuming rainwater harvest rates increase $5 \%$ every year.

\section{RESULT AND DISCUSSION}

The fulfilment of Sentul City's raw water can be seen from two subsystems. Two subsystems are the demand subsystem and the supply subsystem. The raw water supply subsystem has several important variables as a source of water utilization: PDAM Tirta Kahuripan and wastewater/wastewater. The variables in the demand subsystem consist of domestic needs, commercial and public services. The variables determined based on the interests of stakeholders (actors) influence consumption (Table 1). Stakeholders are determined based on the influence that can be generated and the role in the system (Glicken, 2000; Mirgani and Savenije, 1995), as well as the parties who are directly affected by the policies made (Jansky et al., 2005).

Table 1 Requirement in Sentul City raw water fulfillment system

\begin{tabular}{|c|c|c|}
\hline No & Actors & Requirement \\
\hline \multirow[t]{2}{*}{1} & Sentul City residents & 1. water needs to be fulfilled \\
\hline & & 2. consistent water flow \\
\hline \multirow[t]{3}{*}{2} & PDAM Tirta Kahuripan & 1. water needs of Bogor regency to be fulfilled \\
\hline & & 2. there is no water conflict \\
\hline & & 3. Additional raw water supply \\
\hline \multirow[t]{2}{*}{3} & Environmental Agency, Bogor Regency & 1. Land conversion control \\
\hline & & 2. there is no pollution of water sources \\
\hline \multirow[t]{2}{*}{4} & $\begin{array}{l}\text { Highways and Waterworks Agency, Bogor } \\
\text { Regency }\end{array}$ & 1. the preservation of water resources \\
\hline & & 2. availability of water in public facilities \\
\hline 5 & Commercial area & 1. continuously water supply \\
\hline
\end{tabular}


PDAM Tirta Kahuripan plays a role as a water supplier for the Sentul City area. Residents of Sentul City, commercial areas are consumers who are affected by the policies implemented. Local governments represented by related agencies influence the policies implemented. The framework for meeting the raw water needs in Sentul City can be described in a black-box diagram. Black box diagrams require input and output, which will be used as feedback as a system improvement (Figure 2).

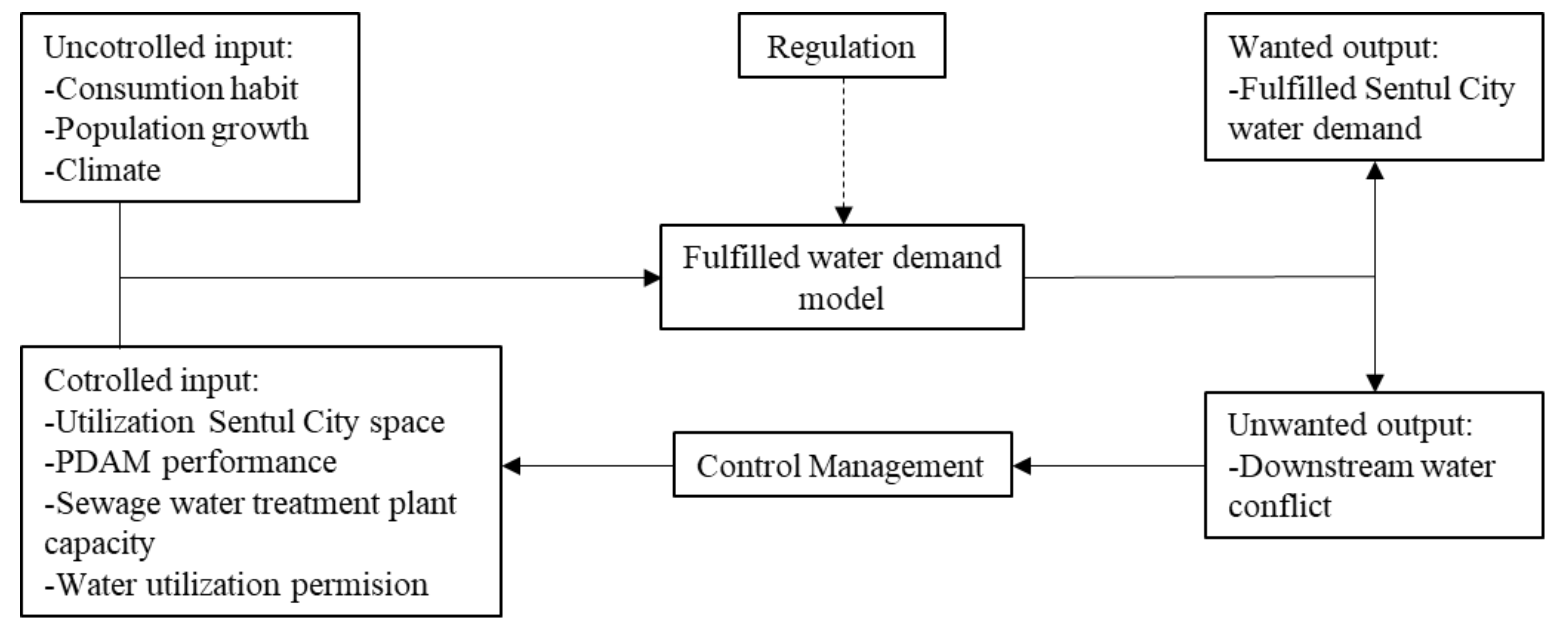

Figure 2 Black-box diagram of Sentul City water fulfillment system

The relationship between variables in the system is depicted in the causal loop diagram. The causal loop diagram is divided into two subsystems. The demand subsystem describes water consumption in Sentul City, and the supply subsystem describes the source of water supply for the Sentul City area (Figure 3 and 4 ). The water supply from PDAM Tirta Kahuripan and wastewater water treatment is constant base on maximal capacity, and potential rainwater harvesting in the Sentul City area is $27868884 \mathrm{~m}^{3} / \mathrm{year}$. The water supply subsystem contained some significant variables. The total water supply of Sentul City is affected by water treatment, wastewater treatment, regional water company supply, and rainwater harvesting (in the scenario). A positive sign means, increasing the variable can cause an increased total water supply. In the scenario, the relation between water balance and rainwater harvesting means that if water balance has a positive value, the attempt to harvest rainwater decreases. In scenario 2 assumed that every increasing water supply followed by increased wastewater treatment due to the design of an independent city that must be able to recycle its water according to the capacity of its inhabitants.

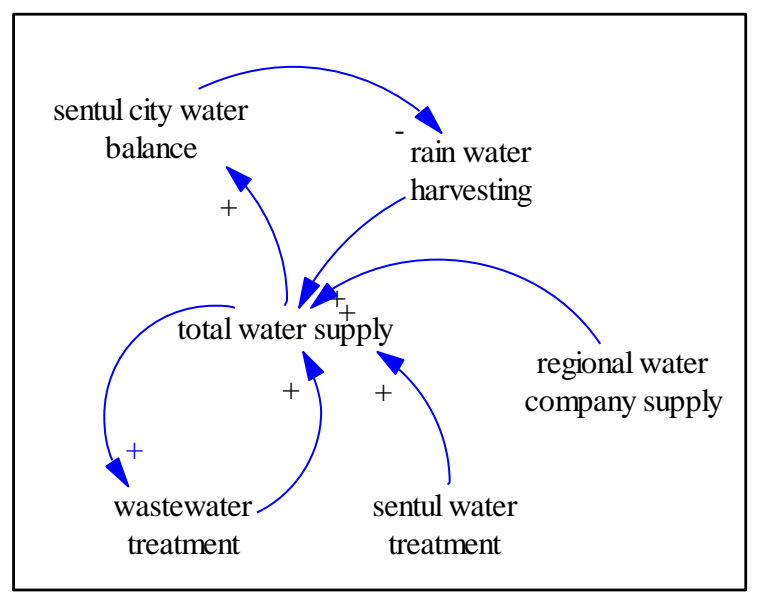

Figure 3 Causal loop diagram of water supply subsystem 
The water demand subsystem contained three significant variables, domestic, public facility, and commercial area water consumption - all three variables affected by the Sentul City population. Increasing the city population can reduce potential areas because of housing needs and increased water consumption in all sectors. The total water consumption assumed will continue to increase until the capacity of Sentul City is fulfilled. Therefore, in this model, the total water consumption, in general, depends on Sentul City capacity, in this case is the area.

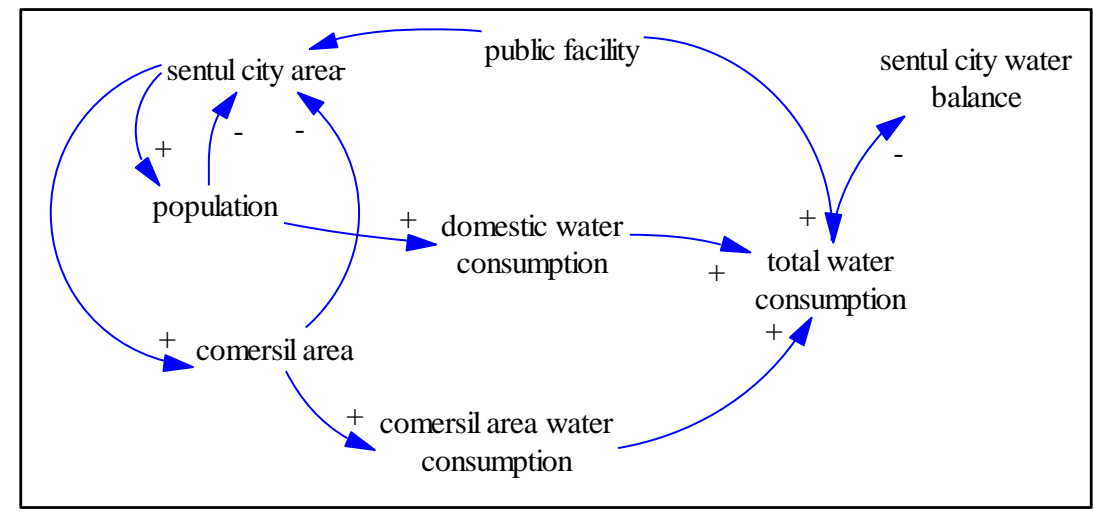

Figure 4 Causal loop diagram of water demand subsystem

The result of system dynamic model simulation, in the base model (BAU scenario), the Sentul City water demand is estimated in 2013 (at the start of simulation) reach to $4185420 \mathrm{~m}^{3}$, reaching $122105000 \mathrm{~m}^{3}$ in 2050. The assumption in the base model is water supply in Sentul Area is constant base on a water supply capacity $9268080 \mathrm{~m}^{3} / \mathrm{year}$. The model simulation results show that the increase in water needs is caused by the domestic sector, which increases with the increasing population (Figure 5). However, population growth will be starting a decrease in 2037 due to the reduced capacity of Sentul City.

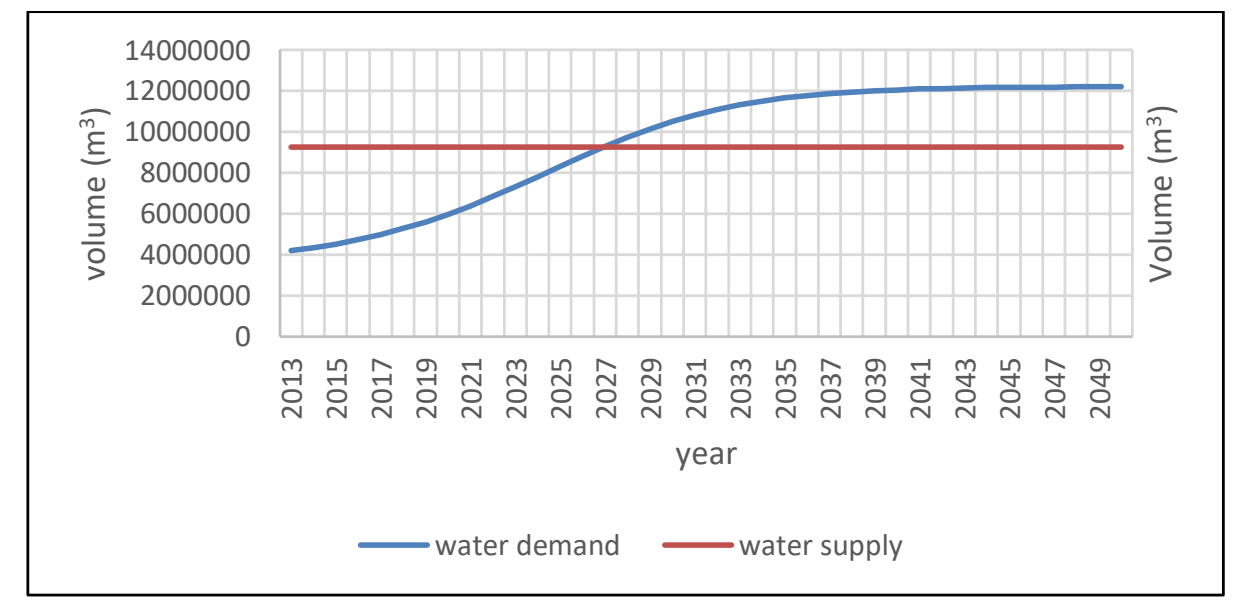

Figure 5 Water supply and demand of Sentul City simulation

Water availability in the simulation model shows a significant increase in scenario 3. Increased water supply through wastewater recycling and rainwater harvesting provide a significant potential for water availability. The diagram below shows that scenario two utilization of wastewater recycling can increase water availability by $150 \%$, and scenario three recycling wastewater and harvesting rainwater can increase water availability by $204 \%$ in Sentul City. It is assumed that the rainwater harvesting efforts in scenario three will start in 2025 (Figure 6). 


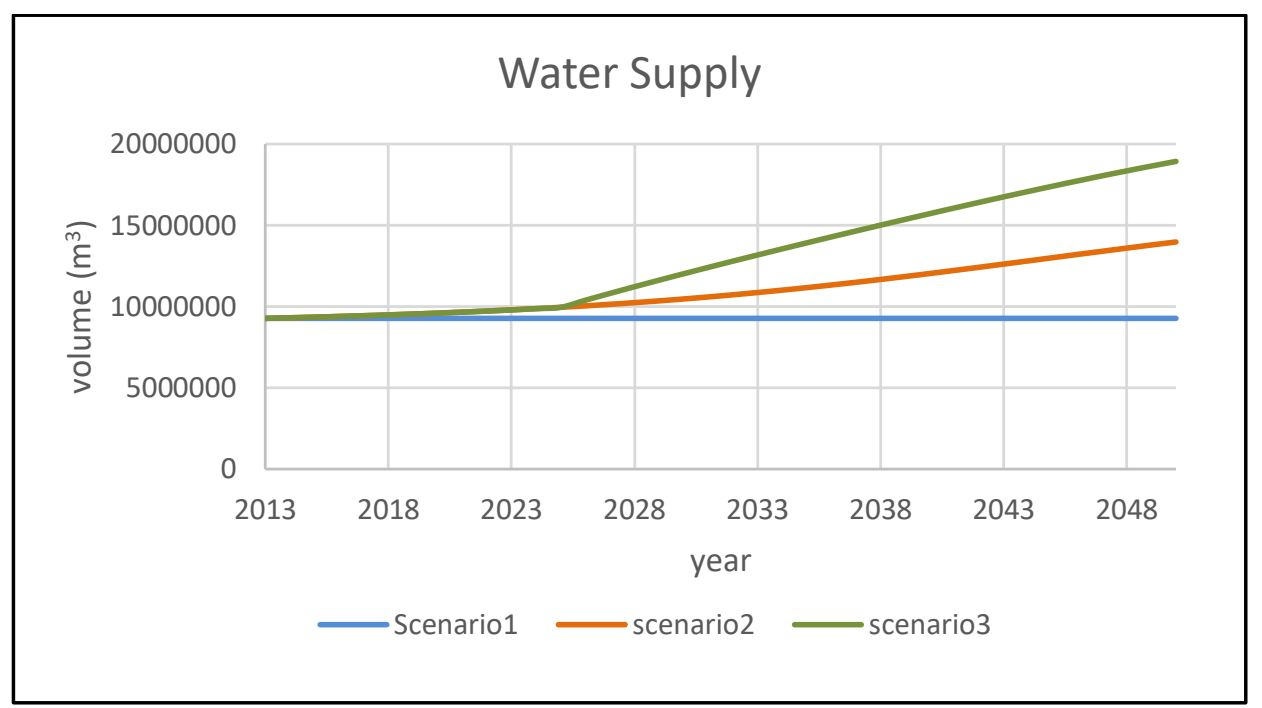

Figure 6 Water supply subsystem simulation

Sentul city water balance estimation in scenario 1 (BAU), shows a potential water crisis in 2027 due to the absence of additional water supply from PDAM or regional wastewater treatment, which causes water demand to be greater than water availability. Scenario 2, the water crisis that will occur in 2027 can be inhibited until 2030. The negative water balance will last until 2040 so that in scenario two, an additional supply of sufficient water is required for up to 10 years. The water balance is predicted to return to a positive value in 2041 due to the addition of the planned wastewater recycling capacity (Figure 7).

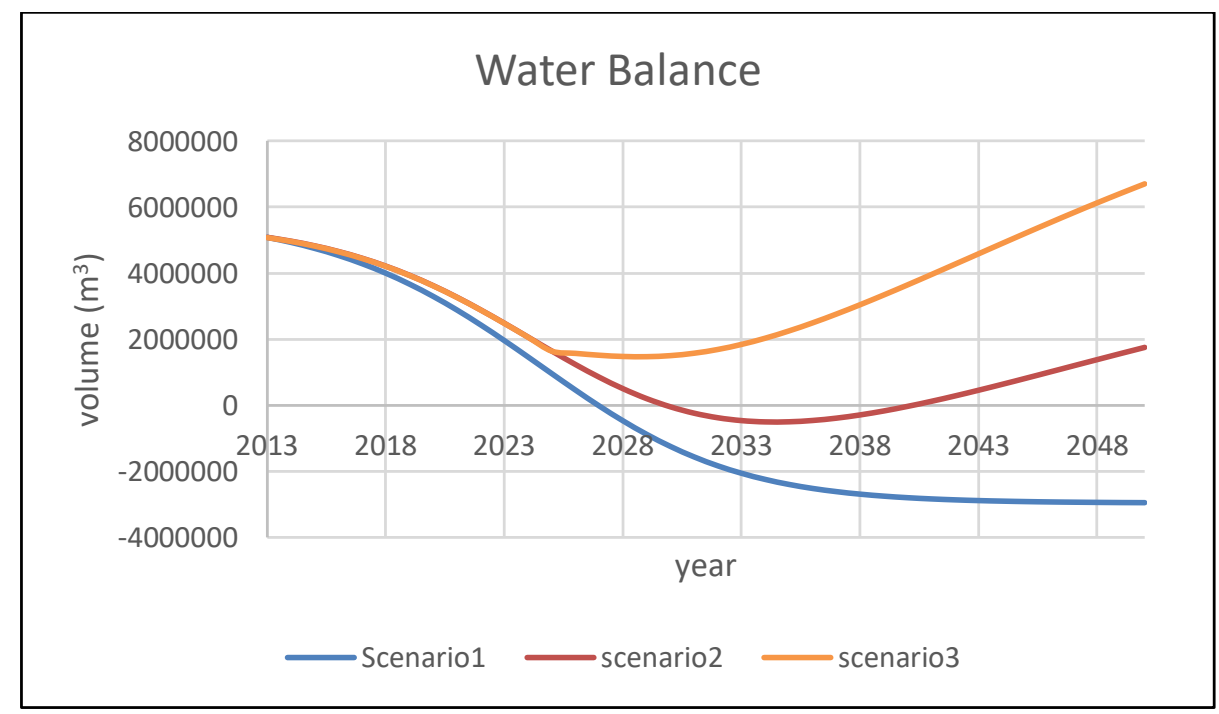

Figure 7 Water balance simulation

The water supply needed to meet water needs in scenario 2, in this simulation model, is obtained from rainwater harvesting used as scenario 3 in the simulation. Scenario 3 shows that in 2025 the water balance will decline insignificantly and tends to slope so that in 2030 the water balance is expected to increase. Harvesting rainwater at a rate of $5 \%$ potential rainwater harvesting per year can prevent Sentul City from a water crisis. Scenario 3 in the model shows that the water balance never indicates a negative value until the area's carrying capacity reaches its maximum limit. 


\section{CONCLUSION}

The Sentul City Water demand will reach $122105000 \mathrm{~m}^{3}$ in 2050 that caused a water crisis in 2027. Implementation of wastewater treatment with $65 \%$ efficiency can increase water availability by $150 \%$ and inhibited water crisis to 2030, then can fulfill water need in 2041. The Sentul City water balance can sustain with rainwater harvesting in 2025 with rate of $5 \%$ of potential rainwater harvesting per year.

\section{ACKNOWLEDGEMENT}

The researcher would like to thank The Osaka Gas Foundation of International Cultural Exchange (OGFICE) for funding this research and the Center for Environmental Research (ERC-IPB) for supporting the research to completion. Hopefully, this research can be useful for development in urban area.

\section{DAFTAR PUSTAKA}

[BAPPENAS] Badan Perencanaan Pembangunan Nasional. 2019. Bahan Presentasi Kajian Lingkungan Hidup Strategis (KLHS) Calon Ibu Kota Baru Penjam Pasar Utara. Jakarta (ID): BAPENAS.

Baskoro DAP, Purwanto MYJ, Solahudin M. 2020. Watershed based model for water allocation. IOP Confrence series: Earth an Environmental Science. 542: 1-9.

Brown RR. 2008. Local institutional development and organizational change for advancing sustainable urban water futures. Environmental Management. 41: 221-233.

Brown RR, Keath N, Wong THF. 2009. Urban water management in cities: historical, current and future regimes. Water Science and Technology. 59(5): 847-855. doi: https://doi.org/10.2166/wst.2009.02.

Glicken J. 2000. Getting stakeholder participation 'right': a discussion of participatory processes and possible pitfalls. Environmental Science \& Policy. 3: 305-310.

Harahap S. 2018. Evaluasi landskap bagi peruntukan situ di Sentul City [tesis]. Bogor (ID): Institut Pertanian Bogor.

Hermawan A, Purwanto MYJ, Pandjaitan NH. 2020. Analisis kesesuaian lokasi bending kecil dan daerah pemanenan air hujan dengan menggunakan system informasi geofgrafis di wilayah perkotaan. TATA LOKA. 22(2): 188-201.

Jansky L, Uitto J. 2005. Enhancing Participation and Governance in Water Resources Management: Conventional Approaches and Information Technology. Tokyo (JP): United Nation University Press.

Jun WX, Yun ZJ, Shahid S, Mahdi AE, Min HR, Xin BZ, Ali M. 2012. Water resources management strategy for adaptation to droughts in China. Mitigation and Adaptation Strategies for Global Change. 17: 923937.

Koushali HP, Moshtagh R, Mastoori R. 2015. Water resources modelling using system dynamic in Vensim. Journal of Water Resource and Hydraulic Engineering. 4(3): 251-256.

Li S, Yu W. 2010. Urban water balance analysis by holistic approach. Conference on environmental pollution and public health. Scientific Research. 1284-1289.

Mirgani MM, Savenije HH. 1995. Incorporation of people's participation in planning and implementation of water resources project. Physics and Chemistry of the Earth. 20(3-4): 229-236.

Meyer PS, Ausubel JH. 1999. Carrying capacity: a model with logistically varying limits. Technological Forecasting and Social Change. 61(3): 209-214.

Park S, Sahleh V, Jung SY. 2015. A system dynamics computer model to assess the effects of developing an alternate water source on the water supply systems management. Procedia Engineering. 119: 753-760. 